\title{
CORRELATION BETWEEN PARENTAL SOCIALIZATION AND TEACHING AND ATTITUDES TOWARDS INDEBTEDNESS AMONG PORTUGUESE HIGHER EDUCATION STUDENTS
}

\section{MARIA ISABEL RIBEIRO \& ANTÓNIO FERNANDES}

Institute Polytechnic of Bragança, Campus de Santa Apolónia, 5300-253, Bragança, Portugal

\section{Introduction}

Young people's attitudes towards money, which include higher education students, is one of the most studied research issues that is part of consumer socialization theme [1] and has been a common cause of concern among economists, psychologists and sociologists for more than three decades [2]. With the emergence of a global consumption culture, money has assumed an increasingly important role in people's lives [3]. Money-related attitudes are learned through the process of socialization established in childhood and maintained throughout adult life [4]. Attitudes and behaviors related to money determine the management and the financial well-being of an individual [5].

\section{Objective}

To analyze the correlation between students' attitudes towards indebtedness and parental teaching and parental socialization.

\section{Methodology}

A study with a cross-sectional design was developed based on an accidental sample of 1290 students aged between 16 and 43 years old. To collect the data, a questionnaire was directly administered during October and November 2016 The questionnaire had questions about socio-demographic, parental socialization, parental teaching and attitudes towards indebtedness. To measure parental socialization and parental teaching, seven variables were used. Parental socialization involves the use of four variables and intended to measure the relation between the perception of parental socialization practices and student's values. Parental teaching used three variables and aimed to measure the parents' role in teaching responsible credit and money management practices. Finally, twelve variables representing negative attitudes (fear of debt) and positive attitudes (debt utility) [5] were used to evaluate students' attitudes towards indebtedness. All variables, except for socio-demographic variables, were classified in a Likert scale of 5 points ( 1 - totally disagree, 2 - disagree, 3 neither agree nor disagree, 4 - agree, 5 - totally agree). To analyze the data, it was used the IBM SPSS 24.0 software in order to compute: (1) relative and absolute frequencies for qualitative variables; (2) measures of central tendency and dispersion for quantitative variables; (3) Spearman test to study the correlation between ordinal variables; and (4) Cronbach Alfa to analyze the reliability and the internal consistency of the answers. A significance level of $5 \%$ was used.

\section{Results}

As shown in Table 1 , the majority of students was female $(53.4 \%)$, had Portuguese nationality ( $82.3 \%)$, attended an undergraduate course $(68.2 \%)$, and lived in households of 3 or 4 people $(37.4 \%$ and $34.9 \%$, respectively) with a monthly income up to 800 Euros (43.7\%). The parents had educational qualifications at the level of the 3 rd cycle or secondary education $(54.1 \%)$. The mean age was 20.9 years old $(S D=2.9)$. The Cronbach Alpha for parental socialization, parental teaching and students' attitudes towards indebtedness was $0.781,0.818$ and 0.700 , respectively. The overall Cronbach Alfa was 0.833 (Table 2). That is, the overall reliability of the answers was good. Results regarding parental socialization and parental teaching dimensions show a good reliability of the descriptors used. The reliability of students' attitudes towards indebtedness dimension descriptors was no more than fair, however within acceptable limits.

\begin{tabular}{|c|c|c|c|}
\hline Variable & Categories & $\mathrm{n}$ & $\%$ \\
\hline & Male & 600 & 46.6 \\
\hline$(N=1287)$ & Female & 687 & 53.4 \\
\hline Nationality & Portuguese & 1029 & 82.3 \\
\hline$(N=1250)$ & Other & 221 & 17.7 \\
\hline Attended cou & Higher professional technician & 293 & 23,0 \\
\hline \multirow{2}{*}{$(N=1276)$} & Undergraduate & 870 & 68,2 \\
\hline & Post-graduate/master & 113 & 8,9 \\
\hline Household & 1 person & 73 & 5.8 \\
\hline \multirow{4}{*}{$(N=1248)$} & 2 people & 153 & 12.3 \\
\hline & 3 people & 467 & 37.4 \\
\hline & 4 people & 436 & 34.9 \\
\hline & 5 or more people & 119 & 9.5 \\
\hline \multirow{6}{*}{$\begin{array}{l}\text { Monthly income level } \\
(\mathrm{N}=1265)\end{array}$} & Less than 450 Euros & 150 & 11.9 \\
\hline & 451 to 600 Euros & 202 & 16.0 \\
\hline & 601 to 800 Euros & 201 & 15.9 \\
\hline & 801 to 1000 Euros & 291 & 23.0 \\
\hline & 1001 to 1400 Euros & 236 & 18.7 \\
\hline & More than 1400 Euros & 185 & 14.6 \\
\hline \multirow{6}{*}{$\begin{array}{l}\begin{array}{l}\text { Father's educational } \\
\text { level } \\
(N=1264)\end{array} \\
(N=100\end{array}$} & Less than $1^{\text {st }}$ cycle & 39 & 23.1 \\
\hline & $1^{\text {st }}$ cycle & 156 & 12.3 \\
\hline & $2^{\text {nd }}$ cycle & 189 & 15.0 \\
\hline & 3th cycle & 331 & 26.2 \\
\hline & Secondary education & 353 & 27.9 \\
\hline & Higher education & 196 & 15.5 \\
\hline \multirow{6}{*}{$\begin{array}{l}\text { Mother's } \\
\text { level } \\
(\mathrm{N}=1283)\end{array}$} & Less than $1^{\text {st }}$ cycle & 37 & 2.8 \\
\hline & $1^{\text {st }}$ cycle & 115 & 9.0 \\
\hline & $2^{\text {nd }}$ cycle & 204 & 15.9 \\
\hline & 3th cycle & 306 & 23.9 \\
\hline & Secondary education & 388 & 30.2 \\
\hline & Higher education & 233 & 18.2 \\
\hline
\end{tabular}

Table 2 - Dimensions descriptors reliability

\begin{tabular}{|l|c|c|}
\hline Dimensions & $\begin{array}{c}\text { Cronbach } \\
\text { Alfa }\end{array}$ & Reliability \\
\hline Parental socialization & 0.781 & Good \\
\hline Parental teaching & 0.818 & Good \\
\hline Students' attitudes towards indebtedness & 0.700 & Fair \\
\hline Overall & 0.833 & Good \\
\hline
\end{tabular}

Table 3 shows statistically, significant, positive and weak correlations between students' attitudes towards indebtedness and parental socialization (Rho $0.137 ;$ Sig. $=0.000)$ as well as between students' attitudes towards indebtedness and parental teaching (Rho $=0.132 ;$ Sig. 0.000). Parenta teaching contributes to the greater financia well-being of their children and to greater overall satisfaction with life and improves academic performance.

Table 3 - Correlation between students' attitudes towards indebtedness and parental socialization and parental teaching

\begin{tabular}{|l|c|c|c|c|}
\hline Dimensions & Statistics & $\begin{array}{c}\text { Students' attitudes } \\
\text { towards indebtedness }\end{array}$ & $\begin{array}{c}\text { Parental } \\
\text { socialization }\end{array}$ & $\begin{array}{c}\text { Parental } \\
\text { teaching }\end{array}$ \\
\hline \multirow{2}{*}{$\begin{array}{l}\text { Students' attitudes } \\
\text { towards indebtedness }\end{array}$} & Spearman's Rho & 1.000 & & \\
\cline { 2 - 5 } & Sig. & ----- & & \\
\cline { 2 - 5 } & $\mathrm{N}$ & 1199 & & \\
\hline Parental \\
socialization & Spearman's Rho & $0.135^{* *}$ & 1.000 & \\
\cline { 2 - 5 } & Sig. & 0.000 & ---- & \\
\cline { 2 - 5 } & $\mathrm{N}$ & 1188 & 1230 & 1.000 \\
\hline \multirow{2}{*}{$\begin{array}{l}\text { Parental } \\
\text { teaching }\end{array}$} & Spearman's Rho & $0.132^{* *}$ & $0.548^{* *}$ & ---- \\
\cline { 2 - 5 } & $\mathrm{Sig.}$ & 0.000 & 0.000 & 1234 \\
\cline { 2 - 5 } & $\mathrm{N}$ & 1191 & 1219 & \\
\hline
\end{tabular}

\section{Conclusion}

Parental financial behavior, as monthly expenditure monitoring, savings and investments, as well as dialogue with children about how to spend and save money seems to have a positive contribution to students' attitudes towards indebtedness. In spite of that, higher education institutions have a role to play, equally important, in the financial training of the students, independently of the scientific area of training.

\section{ACKNOWLEDGEMENTS}

This work is supported by: the European Structural and Investment Funds in the FEDER component, through the Operational
Competitiveness and Internationalization Programme (COMPETE 2020) [Project No. 006971 (UID/SOC/04011)l; and national funds, Competitiveness and Internationalization Programme (COMPETE 2020) [Project No. 006971 (UID/SOC/04011)];
through the FCT - Portuguese Foundation for Science and Technology under the project UID/SOC/04011/2013.

REFERENCES

[1] Köiv, K. (2013). University students: attitudes towards characteristics of money before, after and during dual currency period in [2] Falahati, L. \& Paim, L. (2011). A comparative study in Money Attitude among University Students: A Gendered View. Journal of American Science, 27(6),1144-1148.

[3] Carvalho, S. (2015). Atitudes face ao dinheiro, compra por impulso, compra compulsiva e materilist [4] Tumg T. Tas. D. \& Luna-Arocas, R. (2005) Money profiles: The love of meney, attitudes, and

603-618.

[5] (3): $322-330$ 